Received: August 2014

Accepted: December 2014

ISSN $2006-6996$

\title{
ASSESSMENT OF THE EFFECT OF DIHYDROARTEMISININ-SODIUM VALPROATE COMBINATION ON SOME BEHAVIOURAL ACTIVITIES IN MICE
}

\author{
Malami, S. ${ }^{1}$, Yaro, A.H. ${ }^{2}$, Ya'u, J. ${ }^{1}$, Idris, A.G. ${ }^{1}$ and Ahmadu, H. ${ }^{1}$ \\ ${ }^{1}$ Department of Pharmacology and Therapeutics, Ahmadu Bello University, Zaria, Nigeria. \\ ${ }^{2}$ Department of Pharmacology, Bayero University, Kano, Nigeria. \\ Correspondence author: malamisani@gmail.com
}

\begin{abstract}
Co-morbidity inevitably warrant occurrence of polypharmacy that may result in interactions or modification of either the therapeutic or toxic effect of any of the drugs employed. Malaria and epilepsy have been known to occur concurrently as such may necessitate the co-administration of two or more drugs. This study evaluated the effect of dihydroartemisinin-valproate combination on some behavioral activities related to central nervous system. The study was conducted using animal models as follows: maximal electroshock-induced seizures test in mice, diazepam-induced sleep in mice and mouse beam walking test for motor coordination deficit. Generally, the results showed that there were no statistical significant effects in the test models. Therefore, dihydroartemisinin did not significantly influence the protective effect of sodium valproate in convulsion; and did not significantly cause sedation in animals. Hence, the result of this study suggests that dihydroartemisinin-sodium valproate combination could be considered safe in seizures condition.
\end{abstract}

Keywords: Dihydroartemisinin, Polypharmacy, Valproate, Drugs, Epilepsy

\section{INTRODUCTION}

Epilepsy is currently defined as the occurrence of at least one seizure with an enduring alteration in the brain structure or function that increases the likelihood of future seizures (Gerlach and Krajewski, 2010). Recent estimates suggest that it accounts for $1 \%$ of the global burden of the disease and affects over 65 million people. Epilepsy is the most common neurological disorder, affecting individuals at all age groups. It remains a common childhood neurological disorder in Nigeria, with large burden of symptomatic epilepsy (Lagunju et al., 2012). Thus, epilepsy imposes a large economic burden on global health care systems and is a major public health problem in low and middle-income countries (Mbuba and Newton, 2009). It is the most common non-infectious neurologic disease in developing African countries, including Nigeria and it remains a major medical and social problem (Ogunrin, 2006). Malaria is a major health concern in Nigeria and other parts of Subsaharan Africa (WHO, 2004). Currently, drugs for treatment of uncomplicated malaria are Artemisinin based combination therapies (FMH, 2005). Valproate is known to have multiple mechanisms of action; it is effective in many kinds of epilepsy and relatively free from unwanted effects associated with other antiepileptic drugs (McNamara, 2006). This work is aimed at assessing the effect of co-administration of dihydroartemisinin and sodium valproate on some behavioural activities related to central nervous system in mice.

\section{MATERIALS AND METHODS}

Animals: Seventy six Swiss Albino mice (18-24 g) of both sexes were used for the experiments. They were obtained from Animal House, Department of Pharmacology and Therapeutics, Ahmadu Bello University, Zaria. The animals were kept in plastic cages with constant supply of standard animal feeds and water ad libitum; maintained at room temperature and $12 \mathrm{~h}$ light/dark cycle; and allowed to acclimatize with the laboratory environment for at least 3 days prior to the commencement of the experiments.

Drugs: The following drugs were used:

Dihydroartemisinin (Cotecxin- Jiaxing Nanhu China), Valproate (Epillin- Sanofi UK), Diazepam (ValiumRoch UK).

\section{Methods}

Maximal electroshock-induced seizure test in mice

For maximal electroshock test, the method of Swinyard and Kupferberg (1985) was adopted. Twenty eight mice were randomly divided in to four groups (G) of seven mice each. G I and G II were given a daily dose of dihydroartemisinin (p.o.) for seven days (Day 1: $2 \mathrm{mg} / \mathrm{kg}$; Days 2-7: $1 \mathrm{mg} / \mathrm{kg}$ ). On the day eight, $200 \mathrm{mg} / \mathrm{kg}$ of valproate was administered (p.o.) to G I and G III; and normal saline $(10 \mathrm{ml} / \mathrm{kg}$ ) to $\mathrm{G}$ IV. After an hour, maximal electroshock was applied to the mice to induce seizures. Episodes of tonic hind limb extension (THLE) were observed. 


\section{Diazepam-induced sleeping time in mice}

The method explained by Wambebe (1985) was employed to assess the effect of valproate and dihydroartemisinin combination on the sedative activity of diazepam in mice. Twenty four mice were randomly divided in to four groups (G) of six mice each. The G I and G II were given a daily dose of dihydroartemisinin (p.o.) for seven days (Day 1: 2 $\mathrm{mg} / \mathrm{kg}$; Days 2-7: $1 \mathrm{mg} / \mathrm{kg}$ ). At the $8^{\text {th }}$ day, $200 \mathrm{mg} / \mathrm{kg}$ of valproate was administered (p.o) to G I and G III; and normal saline (10 ml/kg, p.o.) to G IV. After an hour post treatment, all the groups were administered $20 \mathrm{mg} / \mathrm{kg}$ of diazepam (i.p.); onset and duration of sleep were observed and recorded.

\section{Beam walking test for motor coordination deficits in mice}

The method described by Stanley et al. (2005) was employed. Twenty four mice were randomly divided in to four groups (G) of six mice each. They were trained to travel from a start platform along a ruler $(80 \mathrm{~cm}$ long, $3 \mathrm{~cm}$ wide) elevated $30 \mathrm{~cm}$ above the bench by metal supports to a metal box. The G I and G II were given a daily dose of dihydroartemisinin (p.o.) for seven days (Day 1: $2 \mathrm{mg} / \mathrm{kg}$; Days 2-7: $1 \mathrm{mg} / \mathrm{kg}$ ). At the $8^{\text {th }}$ day, $200 \mathrm{mg} / \mathrm{kg}$ of valproate was administered (p.o) to G I and G III; and normal saline $(10 \mathrm{ml} / \mathrm{kg}$, p.o.) to G IV. After an hour post treatment, all the groups were administered $0.5 \mathrm{mg} / \mathrm{kg}$ of diazepam (i.p.), they were allowed for 30 minutes then moved to the beam test. Time taken to move across the beam and number of foot slips were observed and recorded.

\section{Statistical Analysis}

Results are presented in tables and expressed as Mean \pm SEM. The level of significance between means was tested by ANOVA and results were regarded as statistically significant at $\mathrm{P}<0.05$.

\section{RESULTS}

The result showed that there was same quantal protection against occurrence of seizures between the groups that were given valproate alone and that which received dihydroartemisinin and valproate (Table 1 ). Likewise there was no protection against seizures in both normal saline and dihydroartemisinin groups. Therefore, dihydroartemisinin did not affect the protective capacity of valproate against maximal electro-induced seizures.

There was general decrease in both the onset and duration of sleep, although the decrease was not statistically significant (Table 2). It could be said that valproate decreases the onset of action of diazepam. However, the results showed that valproate shortened the duration of sleep which may predict possible ability of valproate to enhance metabolism of diazepam, and hence quick recovery from sleep.

The result of diazepam-induced motor coordination deficit showed a general decrease in time taken to cross the beam, the decrease was significant $(p<0.05)$ in valproate and dihydroartemisinin-valproate treated groups (Table 3). Also, it could be said that dihydroartemisinin reduced the motor coordination deficit induced by diazepam as shown from the number of hind limb slips. But the group treated with valproate alone showed an increase in the number of hind limb slips, although it was statistically not significant.

Table 1: Effect of Dihydroartemisinin-valproate combination on Maximal Electroshock - induced Seizures in Mice

\begin{tabular}{lcccc}
\hline $\begin{array}{l}\text { Group/ } \\
\text { Treatment } \\
\text { (mg/kg) }\end{array}$ & $\begin{array}{c}\text { Quantal } \\
\text { Protection }\end{array}$ & $\begin{array}{l}\text { Protection } \\
\text { against } \\
\text { Seizures (\%) }\end{array}$ & $\begin{array}{c}\text { Mean } \\
\text { Recovery Time } \\
\text { (min) }\end{array}$ & $\begin{array}{c}\text { Mortality Rate } \\
\text { (\%) }\end{array}$ \\
\hline G I DHA+VA & $6 / 7$ & 85.7 & - & 14.28 \\
G II DHA & $0 / 7$ & 0.0 & $1.18 \pm 0.30$ & 14.28 \\
G III VA & $6 / 7$ & 85.7 & - & 14.28 \\
G IV N/saline & $0 / 7$ & 0.0 & $1.67 \pm 0.33$ & 14.28 \\
\hline
\end{tabular}

Values are presented as Mean \pm SEM, $\mathrm{n}=7$ per group; DHA = Dihydroartemisinin (Day 1: $2 \mathrm{mg} / \mathrm{kg}$, Days 2-7: 1 $\mathrm{mg} / \mathrm{kg}), \mathrm{VA}=$ Valproate $(200 \mathrm{mg} / \mathrm{kg}), \mathrm{N} / \mathrm{saline}=$ Normal saline $(10 \mathrm{ml} / \mathrm{kg}), \mathrm{G}=$ Group

\begin{tabular}{llc}
$\begin{array}{l}\text { Table 2: Effect of Dihydroartemisinin-valproate combination on Diazepam-induced Sleep in Mice } \\
\text { Group/Treatment } \\
\text { (mg/kg) }\end{array}$ & $\begin{array}{c}\text { Mean Onset } \\
\text { of sleep (min) }\end{array}$ & $\begin{array}{c}\text { Mean Duration } \\
\text { of Sleep (min) }\end{array}$ \\
\hline G I DHA+VA & $4.17 \pm 0.48$ & $25.00 \pm 3.45$ \\
G II DHA & $6.17 \pm 1.48$ & $27.80 \pm 2.80$ \\
G III VA & $4.83 \pm 0.74$ & $29.17 \pm 8.91$ \\
G IV N/saline & $7.12 \pm 3.49$ & $26.60 \pm 3.50$ \\
\hline
\end{tabular}

Values are presented as Mean $\pm \mathrm{SEM}, \mathrm{n}=6$ per group, DHA= Dihydroartemisinin (Day 1: $2 \mathrm{mg} / \mathrm{kg}$, Days 2-7: 1 $\mathrm{mg} / \mathrm{kg}), \mathrm{VA}=$ Valproate $(200 \mathrm{mg} / \mathrm{kg}), \mathrm{N} / \mathrm{saline}=$ Normal saline $(10 \mathrm{ml} / \mathrm{kg}), \mathrm{G}=$ Group 


\begin{tabular}{|c|c|c|c|}
\hline $\begin{array}{l}\text { Group/ } \\
\text { Treatment }\end{array}$ & $\begin{array}{l}\text { Number of Hind Limb } \\
\text { Slips }\end{array}$ & $\begin{array}{l}\text { Time taken for the } \\
\text { Task (s) }\end{array}$ & Number of Falls \\
\hline$(\mathrm{mg} / \mathrm{kg})$ & & & \\
\hline G I DHA+VA & $5.50 \pm 1.39$ & $7.33 \pm 1.92^{\mathrm{a}}$ & $0 / 6$ \\
\hline G II DHA & $4.83 \pm 0.48$ & $15.50 \pm 3.76$ & $0 / 6$ \\
\hline G III VA & $7.33 \pm 0.52$ & $9.50 \pm 1.75^{\mathrm{a}}$ & $0 / 6$ \\
\hline G IV N/saline+DZ & $5.83 \pm 1.67$ & $21.77 \pm 3.38$ & $0 / 6$ \\
\hline
\end{tabular}

Values are presented as Mean $\pm \mathrm{SEM}, \mathrm{n}=6$ per group, $\mathrm{DZ}=$ Diazepam $(20 \mathrm{mg} / \mathrm{kg}), \mathrm{DHA}=$ Dihydroartemisinin (Day 1: $2 \mathrm{mg} / \mathrm{kg}$, Days 2-7: $1 \mathrm{mg} / \mathrm{kg}), V A=$ Valproate $(200 \mathrm{mg} / \mathrm{kg}), \mathrm{N} / \mathrm{saline}(10 \mathrm{ml} / \mathrm{kg})=$ Normal saline, Significant at $\mathrm{P}<0.05$ (ANOVA)

\section{DISCUSSION}

The result showed that there was same quantal protection against occurrence of seizures between the groups that were given valproate alone and that which received dihydroartemisinin and valproate. Protection against hind-limb tonic extension in the maximal electroshock seizure test predicts anticonvulsant activity of antiepileptic drugs that prevent the spread of seizure discharge from an epileptic focus during seizure activity (e.g. phenytoin, carbamazepine, valproate, oxcarbazepine, and lamotrigine) (Browning, 1992). Thus, these indicate the ability of the antiepileptic agent to serve in the treatment of generalized tonic-clonic and partial seizures (Raza et al., 2001). Antiepileptic drugs that act via this pathway are able to limit the repetitive firing of action potentials by slowing the rate of recovery of voltageactivated sodium ion channels from inactivation, and suppress hind-limb tonic extension in maximal electroshock seizures (Rho and Sankar, 1999). Dihydroartemisinin is a fast-acting blood schizonticide effective in treating the acute attack of malaria; including chloroquine-resistant and cerebral malaria (Rang et al., 2007). Therefore, dihydroartemisinin did not affect the protective effect of valproate against maximal electroshock-induced seizures.

There was general decrease in both the onset and duration of sleep in valproate and dihydroartemisininvalproate treated groups, although the decrease was not statistically significant. The decrease in the duration may be due to enhancement of diazepam

\section{REFERENCES}

Amos, S., Adzu, B., Binda, L., Wambebe, C. and Gamaniel, K. (2001). Neuropharmacological effect of the aqueous extract of Sphoeranthus senegalensis in mice. Journal of Ethnopharmacolg 78: 33-37.

Browning, R. (1992). The electroshock model, neuronal network and antiepileptic drugs. In: Drugs for Control of Epilepsy: Actions on Neuronal Networks in Seizure Disorders, Faingold, C.L., Fromm, G.H. (Eds). CRC press: Boca Raton, FL, pp. 195-211.

FMH, (2005). Federal Ministry of Health National Antimalarial Treatment Policy of Nigeria. pp14-15.

Gerlach, A.C. and Krajewski, J.L. (2010). Antiepileptic drug discovery and development: What have we learned and where are we going? Pharmaceuticals 3: 2884-2899. metabolism or an action on the central mechanisms involved in the regulation of sleep ( $\mathrm{N}^{\prime} \mathrm{G}$ Guemo et al., 1994; Amos et al., 2001). Whereas the decrease in the onset predict the ability of valproate to cause sedation because it is known to increase GABA content of the brain (Rang, et al., 2007). Therefore, the effects observed may be related to these mechanisms.

The result of diazepam-induced motor coordination deficit showed a general decrease in time taken to cross the beam, the decrease was significant $(p<0.05)$ in valproate and dihydroartemisinin-valproate treated groups. However, the increase in the number of hindlimb slips was observed only in valproate treated group. Beam walking test assess benzodiazepineinduced ataxia as a predictor of sedative effects by measuring the extent of motor deficits caused by damage to the motor cortex, and it is highly defined by the extent of foot slips (Stanley et al., 2005). Therefore the combination did not cause significant motor deficits considering its non effect on the major index (hindlimb slips).

\section{CONCLUSION}

Dihydroartemisinin did not influence the protective action of valproate in convulsion; and did not significantly cause sedation in animals. Hence, the result of this study suggests that dihydroartemisininvalproate combination could be considered safe in seizure condition.

Langunju, I., Awusah, T., Takon, I. and Omigbodun, O. (2012). Mental Health Problems in Nigerian Children with Epilepsy: Association and Risk factors, Epilepsy Behaviour 25: 214218.

Mbuba, C.K. and Newton, C.R. (2009). Packages of care for epilepsy in low and middle-income countries. PLos Medicine 6(10): 2009.

McNamara, J.O. (2006) Pharmacotherapy of the epilepsies, in Goodman \& Gilman's Pharmacological Basis of Therapeutics, 11th ed (Brtunton LL, Lazo JS, Parker KL eds), McGraw-Hill, New York, pp 501-526.

N'Gouemo, P., Nguemby-bina, C. and Baldy-moulinier, M. (1994): Some neuropharmacological effects of an ethanolic extract of Maprounea Africana in rodents. Journal of Ethnopharmacology 43: 161-166 
Ogunrin, A.O. (2006). Epilepsy in Nigeria - A review of etiology, epidemiology and management. Benin Journal of Postgraduate Medicine 8(1): 27-51.

Rang, H.P., Dale, M.M., Ritter, J.M. and Flower, R.J. (2007). Antiepileptic Drugs. In: Rang and Dale's Pharmacology. Churchill Livingstone, pp. 581 and 709

Raza, M., Shaheen, F., Choudhary, M.I., Suria, A., Attaur-Rahman, Sombati, S. and DeLorenzo, R.J. (2001). Anticonvulsant activities of the FS-1 subfraction isolated from roots of Delphinium denudatum. Phytotherapy Research 15: 426-430.

Rho, J.M. and Saukar, R. (1999). The pharmacological basis of antiepileptic drug action. Epilepsia 40: $1471-1483$.
Stanley, J.L., Lincoln, R.J., Brown, I.A., McDonald, L.M., Dawson, G.R. and Reynolds, D.S. (2005): The mouse beam walking assay offers improved sensitivity over the mouse rotarod in determining motor coordination deficits induced by benzodiazepine. Journal of Psychopharmacology 19(3): 221-227).

Swinyard, E.A. and Kupferberg, H.J. (1985): Antiepileptic drugs: detection, quantification and evaluation. Fed Proc. 44: 39-43.

Wambebe, C. (1985): Influence of some agents that affect 5-HT metabolism and receptors and nitrazepam-induced sleep in mice. British Journal of Pharmacology 84:185-191.

World Health Organisation, (2004). Scaling up Management of Malaria; Research to Implementation. Geneva, WHO: 11-15 